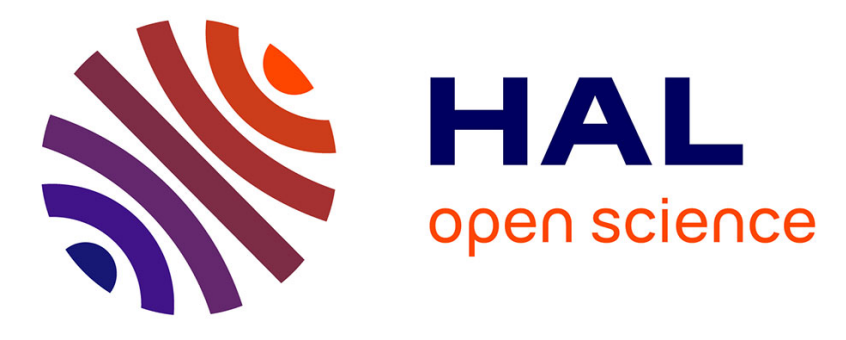

\title{
Phytoextraction from mine spoils: insights from New Caledonia
}

Guillaume Losfeld, Romain Mathieu, Laurent L'huillier, Bruno Fogliani, Tanguy Jaffré, Claude Grison

\section{To cite this version:}

Guillaume Losfeld, Romain Mathieu, Laurent L'huillier, Bruno Fogliani, Tanguy Jaffré, et al.. Phytoextraction from mine spoils: insights from New Caledonia. Environmental Science and Pollution Research, 2015, Combining Phytoextraction and Ecological Catalysis: an Environmental, Ecological, Ethic and Economic Opportunity, 22 (8), pp.5608 - 5619. 10.1007/s11356-014-3866-8 . hal-01898277

\section{HAL Id: hal-01898277 \\ https://hal.umontpellier.fr/hal-01898277}

Submitted on 24 Feb 2021

HAL is a multi-disciplinary open access archive for the deposit and dissemination of scientific research documents, whether they are published or not. The documents may come from teaching and research institutions in France or abroad, or from public or private research centers.
L'archive ouverte pluridisciplinaire HAL, est destinée au dépôt et à la diffusion de documents scientifiques de niveau recherche, publiés ou non, émanant des établissements d'enseignement et de recherche français ou étrangers, des laboratoires publics ou privés. 


\title{
Phytoextraction from mine spoils: insights from New Caledonia
}

\author{
Guillaume Losfeld • Romain Mathieu • Laurent L'Huillier • \\ Bruno Fogliani • Tanguy Jaffré • Claude Grison
}

\begin{abstract}
Increasing pressure on mineral resources has drawn research efforts into innovative supply and recycling. Metalrich biomass produced in phytoextraction recently proved an interesting starting material for green chemistry. It allows the production of new catalysts, referred to as ecocatalysts. Ecocatalysts provide increased yields in chemical production and increased regio- and chemo-selectivity, which result in high added value. This new approach to using metal-rich biomass could spur the development of phytoextraction, a technique considered promising for long, yet without credible economic outlets. In this regard, metallophyte biodiversity hotspots, such as New Caledonia, are of particular interest for biomass supply. Potential phytoextraction from mine spoils using two species endemic to New Caledonia is discussed here. Geissois pruinosa, a hypernickelophore, and Grevillea exul, a Mn accumulator, were selected for these original experiments. The results presented here 20 months after plantation of young trees from a nursery show the interest of the approach. Mean Ni concentrations of up to $1513 \mathrm{mg} \mathrm{kg}^{-1}$ are reported in G. pruinosa, as well as $2000 \mathrm{mg} \mathrm{kg}^{-1} \mathrm{Mn}$ in G. exul. Concentrations of $\mathrm{Ni}$ and $\mathrm{Mn}$
\end{abstract}

G. Losfeld $\cdot$ C. Grison $(\triangle)$

FRE 3673-Bioinspired chemistry and ecological innovation-CNRS, University of Montpellier 2, Stratoz-Cap Alpha, Avenue de l'Europe, 34830 Clapiers, France

e-mail: claude.grison@cnrs.fr

R. Mathieu • L. L'Huillier • B. Fogliani

Institut Agronomique néo-Calédonien (IAC), Diversités biologique

et fonctionnelle des écosystèmes terrestres, 98890 Païta, New

Caledonia

T. Jaffré

UMR AMAP, IRD-Institut de recherche pour le développement, Laboratoire de Botanique et d'Ecologie Végétale Appliquées, 98848 Noumea, New Caledonia in the leaves of each species appear to be correlated with leaf age. Plantation of these species may also ensure mine reclamation, and experiments were conducted with the principles of ecological restoration in mind adding a further dimension to the approach.

Keywords Hyperaccumulation · Phytomining · Phytoextraction $\cdot$ Nickel $\cdot$ Manganese $\cdot$ Ecocatalysis

\section{Introduction}

In spite of technical limits and costs, metals are atoms and they are virtually infinitely recyclable. Thus, they could be considered a renewable resource (Verhoef et al. 2004): They are not consumed but merely transferred from the lithosphere, where they naturally occur, to the so-called 'technosphere', where they are used (Wellmer 2012). The concept of 'peak' introduced by Hubbert (1956) for oil refers to the maximum production before decline and eventual depletion of the resource. 'Peak minerals' were recently discussed by Mudd and Will (2008): Although mining is generally considered unsustainable, current trends show exponentially growing production and increasing economic resources for most mineral commodities. The reserve to consumption ratio often proved a wrong estimate of the time left before depletion of the resource (Wellmer 2012): Prospection efforts may affect reserves, new techniques may allow the exploitation of lowgrade ores and technological shifts may alter consumption trends. Yet tremendously increasing environmental costs could limit further development of mineral production (Mudd and Will 2008). Hence, substitute mineral resources need to be found.

Exploitation of low-grade ores as well as mine tailings or mineral processing wastes can be achieved using plants that are able to accumulate trace elements (TEs) at very high 
concentrations in their aerial biomass (Chaney et al. 2007; Dodson et al. 2012). However, viable economic outlets for such plants have not emerged yet and possible limitations to their use were probably understated (Ernst 2005; SasNowosielska et al. 2004). A new approach emerged late 2009: TE-rich biomass can be turned into efficient ecocatalysts that allow the production of highly valuable molecules (Grison and Escande 2013a, b; Grison and Escarre 2011a, b). Increased yields in chemical reactions (Losfeld et al. 2012a, b; Thillier et al. 2013), increased chemo- and regio-selectivity (Escande et al. 2013, 2014a) and the possibility to access new molecules (Escande et al. 2014b; Grison et al. 2013) make ecocatalysts more than simple substitutes: They offer a whole lot of new possibilities for green chemistry, with potential paradigm shifts.

New Caledonia, an archipelago of the Melanesian pacific subregion, is covered by $5600 \mathrm{~km}^{2}$ of ultramafic outcrops. Part of this surface area contains 'Ni-rich laterites' that may account for $16 \%$ of the world Ni resources (Losfeld et al. 2014a). The ultramafic outcrops of New Caledonia also host a very interesting biodiversity: 2153 species have been identified so far on such terranes, with an endemism of $82 \%$. Among these species, various TE accumulators and hyperaccumulators are found (L'Huillier et al. 2010). Among early reports of high $\mathrm{Ni}$ or Mn concentrations in plant leaves, some of the most significant originate from New Caledonia (Brooks et al. 1981; Jaffré 1977, 1979; Jaffré and Schmid 1974). In total, New Caledonia hosts $65 \mathrm{Ni}$ hyperaccumulators (Jaffré et al. 2013) as well as $11 \mathrm{Mn}$ hyperaccumulators (Losfeld et al. 2014b). Thus, it appeared crucial to investigate the possibility of producing biomass for Ecocatalysis using Ni- and Mn-hyperaccumulating species from New Caledonia.

\section{Developing applications for trace element hyperaccumulators}

Trace element hyperaccumulation

The term 'hyperaccumulator' appeared for the first time in a report from New Caledonia to describe the extraordinary ability of Pycnandra acuminata (ex. Sebertia acuminata) to accumulate Ni in its aerial tissues (Jaffré et al. 1976). It was then generally used to describe plant species, for which a concentration of $\mathrm{Ni}$ above $0.1 \%$ had been reported in the dry leaves of at least one individual in its natural habitat (Reeves 1992). Active uptake only should be taken into account, and direct deposition of soil particle on leaves should be taken care of as a potential perturbation on measurements (Faucon et al. 2007). Since then, about $450 \mathrm{Ni}$ hyperaccumulators have been identified worldwide (van der
Ent et al. 2013a) along with 22 Mn hyperaccumulators (Losfeld et al. 2014b).

Although not always considered relevant (van der Ent et al. 2013a), studies of the flora of New Caledonia led to using a specific terminology: Numerous species from the archipelago are found to accumulate $\mathrm{Ni}$ in their dry leaves at levels above $1 \%$. This is 1 order of magnitude higher than hyperaccumulation and such species were termed 'hypernickelophore' (Jaffré and Schmid 1974). So far, 16 such species have been identified in New Caledonia (Jaffré et al. 2013). Ongoing studies should reveal the molecular mechanisms underlying such high $\mathrm{Ni}$ levels in plants (Merlot et al. 2014). As regards to Mn, numerous species from New Caledonia are known to accumulate this element at concentrations ranging from 0.3 to $1 \%$ in their dry leaves (Losfeld et al. 2014b). Although under the hyperaccumulation threshold, such species can be used to prepare Mn-rich ecocatalysts (Grison and Escande 2013a).

\section{Designing applications}

From their discovery, TE hyperaccumulators raised tremendous expectations for the development of commercial applications that are generally referred to as TE phytoextraction (Robinson 1997). Two approaches devised during the late 1880s were developed (Baker et al. 1988): Phytoremediation by way of phytoextraction was seen as a cost-effective method to clean up contaminated soil (Chaney et al. 1997; Kumar et al. 1995), while phytomining, initially termed biomining (Cunningham and Berti 1993), appeared as a relevant strategy to recover TEs.

\section{Phytomining}

Phytomining was not seen to have the most potential (Baker et al. 1988) but was nonetheless developed with industrial views (Brooks et al. 1998). Selective breeding of Alyssum species was performed along with the development of agronomic practices to ensure biomass supply (Chaney et al. 2000; Li et al. 2003). Ni-rich ashes obtained from the biomass could be treated along with Ni ores using pyrometallurgical processes (Brooks et al. 1998). Issues with Alyssum cultivars becoming invasive (Oregon Department of Agriculture 2014), poor results using Alyssum species in tropical areas (van der Ent et al. 2013b) and current turmoil in the Ni industry will probably hinder further development of the technique. Inherent limits also need to be emphasised: Phytomining cannot exploit the extraordinary ability of plants to accumulate $\mathrm{Ni}$ because the end product is similar to that obtained from pyrometallurgy. Other Ni phytomining projects are currently in development (Bani et al. 2013) and rely on chemical separation techniques to produce a Ni salt (Barbaroux et al. 
2012). Although different from conventional Ni metallurgy, the process still needs to prove its economic significance.

\section{Phytoremediation by way of phytoextraction}

Phytoremediation by way of phytoextraction appeared as a cost-effective mean for cleaning TE-contaminated soil (Raskin and Ensley 2000). Yet, after 20 years of continuing research efforts, the technique has not achieved its full potential. Feasibility, cost-effectiveness (Conesa and Schulin 2010; Ernst 2005; Robinson et al. 2003; Van Nevel et al. 2007), public acceptance (Wolfe and Bjornstad 2002) and the issue of contaminated biomass disposal are still questioned (Ernst 2000; Sas-Nowosielska et al. 2004). As stated by Conesa et al. (2012), 'the commercial success of phytotechnologies depends on the generation of valuable biomass on contaminated land, rather than a pure remediation technique that may not compare favourably with the costs of inaction or alternative technologies'.

\section{Ecocatalysis}

Ecocatalysis is the first unified approach to using TE-rich biomass. Lewis acid ecocatalysts can be prepared from TE hyperaccumulators or accumulators in a simple two-step process (Fig. 1):

1. TE-rich biomass is treated at $550^{\circ} \mathrm{C}$. Water is evaporated and organic matter destroyed without changes in elemental content. TE-rich ashes are obtained in this step.

2. Acid digestion of the ashes is performed, e.g. using $1 \mathrm{M}$ hydrochloric acid with final evaporation and recycling of the acid. A complex mineral powder is finally obtained, which can be used to catalyse organic chemistry reactions.

This is effective regardless of the origin of the biomass. Well-known $\mathrm{Zn}$ and Ni hyperaccumulators can be exploited, but also Mn accumulators and hyperaccumulators (Grison and Escande 2013a). Biomass from phytoremediation or phytomining operations can be used with (Losfeld et al. 2012a; Thillier et al. 2013) or without purification (Escande et al. 2013; Losfeld et al. 2012b). Ecocatalysis allows the synthesis of molecules with potentially high added value, such as anti-cancer monastrol (Escande et al. 2014a; Grison et al. 2013). The essence of catalytic processes requires low amounts of ecocatalysts that are recyclable: Thus, large quantities of chemicals are produced per unit catalyst, with a lesser pressure on biomass supply (Losfeld et al. 2014a). The added value is obtained from chemical retail, and ecocatalysts are then fundamentally different from metals in terms of their market. The generated added value is decorrelated from the metal content of the biomass, avoiding disruptive volatility of the metal markets. In this regard, ecocatalysis currently appears as the most relevant outlet for TE-rich biomass.

\section{Opportunities for phytoextraction in New Caledonia}

General planning of phytoextraction schemes

As appears from recent reviews, existing proposals for planning TE phytoextraction are far from satisfactory (Chaney et al. 2007; Tang et al. 2012), while latest proposals remain conceptual rather than practical (Hunt et al. 2014; van der Ent et al. 2013b). Site-specific approaches are usually required, which limits the scope of each experiment (Tordoff et al. 2000). The case of tropical ecosystems was usually less considered for at least three reasons:

1. The reclamation of closed mines and other TEcontaminated sites occurred earlier in the temperate ecosystems of Western Europe and the USA (Tordoff et al. 2000). Stronger legal requirements regarding contaminated sites and competing land uses also motivate remediation efforts in these regions.

2. Ultramafic outcrops from tropical areas can be naturally rich in Ni and other TE: They cannot be considered as contaminated land.
Fig. 1 General process for the preparation of ecocatalysts

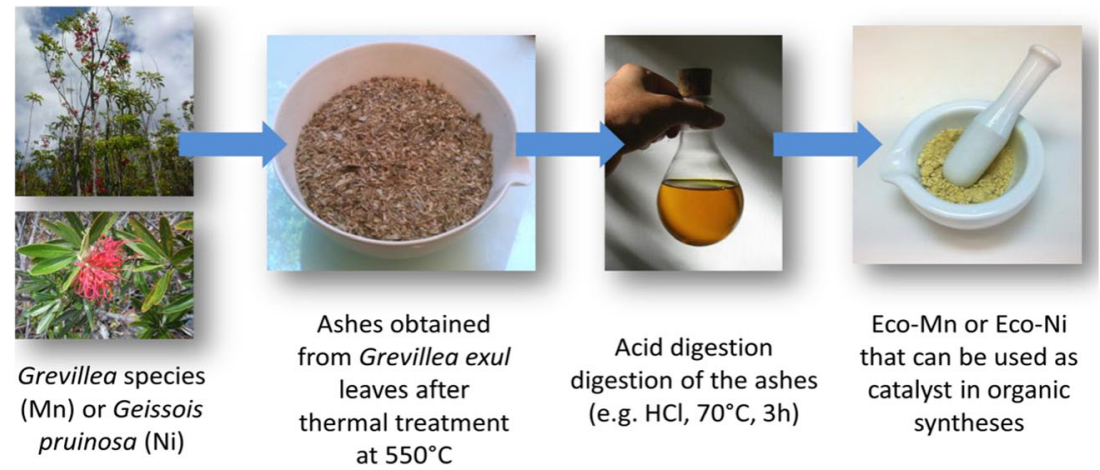


3. The potential of tropical $\mathrm{Ni}$ hyperaccumulators for phytomining appeared lesser compared to other species from temperate areas such as Alyssum murale or Alyssum corsicum (Reeves 2003).

Recent experiments of tropical Ni phytomining using Alyssum species showed poor results (van der Ent et al. 2013b), while Alyssum species used for phytomining in the USA eventually became invasive (Oregon Department of Agriculture 2014). Such observations confirm the interest of developing site-specific approaches relying on locally adapted species.

\section{The New Caledonian context}

TE hypercumulators from New Caledonia are of fundamental ecological interest (Jaffré et al. 2013) and may also play a central part in the development of new applications for TErich biomass (Grison et al. 2013; Losfeld et al. 2012c). New Caledonia is a clearly recognised metallophyte biodiversity hotspot (Jaffré et al. 2013; L'Huillier et al. 2010; Whiting et al. 2004), yet under strong pressure from extensive nickel mining operations (Fig. 2). Mining targets ferritic ferralsols and occurs as follows: vegetation and topsoil are removed along with upper soil horizons of lower Ni content. Direct impacts of the strip mining process are widely seen in New Caledonia with dramatic soil erosion and perturbations of water flows (Losfeld et al. 2014a). The need to store increasing quantities of mine spoils and ore processing waste also produces degraded land (Table 1). Current approach in New Caledonia is to build stabilised piles (Fig. 3). Although precise data on volumes and surface areas affected are not available, the storage of mine spoils is clearly a major issue (Jaffré et al. 2010).
Table 1 Estimation of the quantity of ore extracted from New Caledonia and the resulting spoil production (DIMENC, general Directorate for Industries, Mines and Energy in New Caledonia, 2008)

\begin{tabular}{llll}
\hline Time span & Extracted ore $(\mathrm{t})$ & Ratio spoil/ore & Spoil $(\mathrm{t})$ \\
\hline Before 1920 & $3,048,549$ & 1.0 & $3,048,549$ \\
$1921-1950$ & $5,003,762$ & 1.5 & $7,505,643$ \\
$1951-1975$ & $78,356,696$ & 2.0 & $156,713,392$ \\
$1976-2001$ & $133,118,259$ & 3.5 & $465,913,907$ \\
\hline
\end{tabular}

However, mine spoils are readily available and may contain residual $\mathrm{Ni}$ and $\mathrm{Mn}$ with some potential for phytoextraction.

Reclamation of the areas impacted by mining using plants has been considered for long in New Caledonia in addition to conventional civil engineering (Bradshaw 1997; Cherrier 1990). Simple but useful recommendations emerged from various early experiments:

1. Any type of soil decompaction before plantation is useful;

2. Mulching is a useful way to retain soil humidity;

3. The use of topsoil and fertilisers always significantly improves plants response.

Multiple collaborations resulted in the recent publication of a collective reference book, which assesses the knowledge acquired over 40 years in mine restoration in New Caledonia, makes recommendations on the best available practices in ecological restoration and gives information on the use of about a hundred native plant species (L'Huillier et al. 2010). Hypernickelophore species Geissois pruinosa as well as Mn accumulators of the Grevillea genus were identified as candidates for plantation on degraded areas. Yet the phytomining potential of such species was never assessed. Current
Fig. 2 Ultramafic outcrops from New Caledonia and associated mining operations

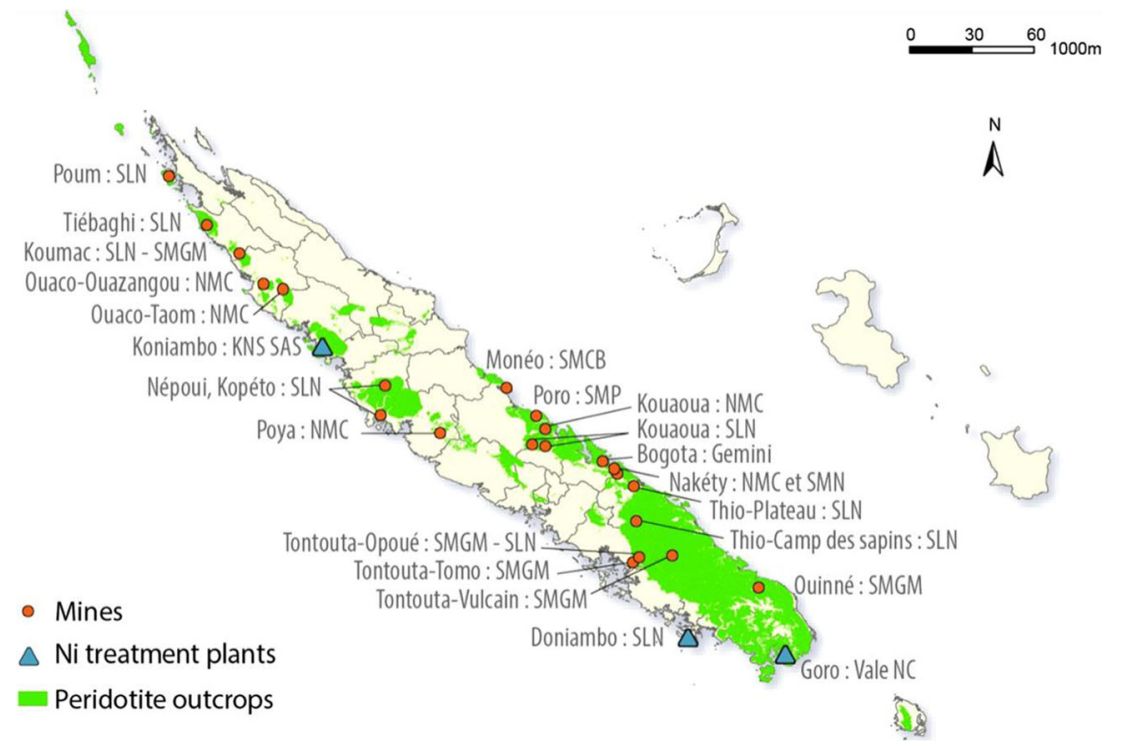




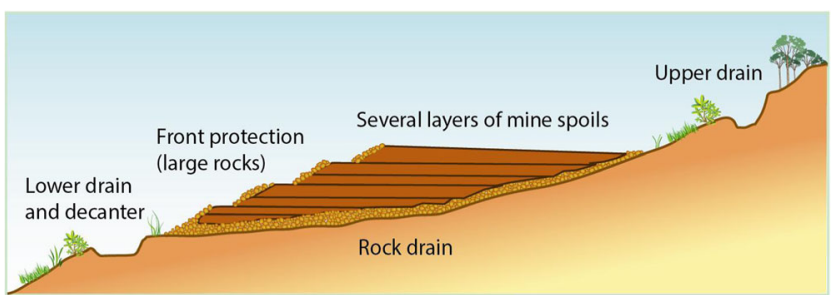

Fig. 3 Schematic of the piles built for the storage of mine spoils in New Caledonia

experiments in New Caledonia are the first to investigate an approach where the plantation of metallophytes on mine spoils would ensure reclamation and provide revenues through the ecocatalysis outlet.

Ongoing experiments at the 'Camp des Sapins' mine, Thio, New Caledonia

\section{Geissois pruinosa}

The Geissois genus (Cunoniaceae family) is composed of 19 species all occurring in Melanesia, with 13 species in New Caledonia. Recent phylogenetic studies showed that Geissois from New Caledonia descended from a single colonist and diversified between 2.3 and 12.1 million years (MY), resulting in the 13 present species (Pillon et al. 2014). Six species are ultramafic obligate, five non-ultramafic, and two ultramafic facultative, and all are endemic to New Caledonia. Seven species of Geissois, including Geissois pruinosa were initially described as Ni hyperaccumulators (Jaffré et al. 1979). Taking latest taxonomic revisions into account (Hopkins and Pillon 2011) and the reference base Florical (Morat et al. 2012), it is now accepted that six species from the Geissois genus are $\mathrm{Ni}$ hyperaccumulators (Jaffré et al. 2013). Three of them, Geissois bradfordii, Geissois lanceolata, and Geissois pruinosa, were reported to accumulate $\mathrm{Ni}$ at concentrations above $1 \%$ and are considered hypernickelophore (Jaffré et al. 2013). However, mean concentration in wild Geissois pruinosa is only $0.61 \%$ (L'Huillier et al. 2010) and may reach $1.5 \%$ (Jaffré et al. 2013).

Geissois pruinosa is a shrub or small tree that can reach $10 \mathrm{~m}$ high. Its leaves are petiolate, opposite and decussate, palmately compound, with three or usually five leaflets. Its bright red inflorescences have a cylindrical shape and are arranged in racemes on the trunk and stems. Fruits are capsules splitting length-wise (two dehiscent splits) to release around 30 seeds per capsule. Each infrutescence can be composed of 10 to 40 capsules. Seeds are slightly winged and are wind-dispersed (Fogliani et al. 2009). This species is common from sea level up to $1000 \mathrm{~m}$; it is heliophilous and grows in scrublands or near the edge of forests where it occurs as little trees (up to $8 \mathrm{~m}$ ); it naturally occurs on magnesic cambisols and various ferritic ferralsols except gravelly ferritic ferralsols and those presenting ferricretes. Latest taxonomic revisions differentiate two varieties (Hopkins and Pillon 2011): Geissois pruinosa var. pruinosa is the most common and occurs throughout the large ultramafic outcrops south of Grande Terre. The other variety, Geissois pruinosa var. intermedia, is rare and occurs northeast of Grande Terre: It was originally described as non-ultramafic, but recent elemental analysis of precisely identified herbarium samples showed $\mathrm{Ni}$ concentrations similar to Geissois pruinosa var. pruinosa from ultramafic soil (Pillon et al. 2014). As regard to Ni sequestration, Geissois pruinosa shows distinct metabolic profiles compared to other species of the Geissois genus (Callahan et al. 2012) which suggests different mechanisms for the storage of this element (Pillon et al. 2014).

The species is considered a pioneer (Pelletier 2006) and is regularly used in revegetation programs because their seed germination is easy, without dormancy (L'Huillier et al. 2010).

\section{Grevillea exul}

The Grevillea genus (Proteaceae family) includes over 550 species endemic to Australia, 3 species endemic to New Caledonia and 4 species occurring in Sulawesi and New Guinea. The three new Caledonian species are shrubs with simple petiolate leaves, strictly restricted to ultramafic substrates (ultramafic obligates) and to the 'maquis'. All three accumulate manganese (Jaffré 1979) and mean Mn concentrations in Grevillea exul leaves are $0.28 \%$ (L'Huillier et al. 2010). Unlike many species of the maquis, they are for a majority not mycorrhizal but have cluster proteoid roots that facilitate mineral nutrition particularly phosphorus (Lamont 2003). No phylogenetic studies were performed for these species. Regarding their adaptation to ultramafic soils, studies were conducted on the seeds of Grevillea exul var. rubiginosa to evaluate the effect of nickel on the germination (Leon et al. 2005) and on the internal distribution of the mineral elements (Rabier et al. 2008). Furthermore, Rabier et al. (2007) studied its growth and metal accumulation capacity, using seven metal salts under controlled conditions: regulation of shoot $\mathrm{Mn}$ and $\mathrm{Ni}$ compared to Brassica juncea was emphasised. However, no studies were developed to characterise the nature of manganese-binding ligands.

Grevillea exul is the most common species of the Grevillea genus. It occurs as shrubs growing in maquis on magnesic cambisols and ferritic ferralsols. It is heliophilous, most often 2 to $4 \mathrm{~m}$ high with some individuals reaching $8 \mathrm{~m}$. It possesses white to off-white unilateral brush-shaped inflorescences grouped into raceme at the end of branches. Fruits are follicles that open at maturity by a lateral split to release two flat seeds slightly winged on their periphery, dispersed by the wind. Two subspecies are recognised in the reference base Florical (Morat et al. 2012). Grevillea exul ssp. exul possesses linear leaves and a silvery white pubescence on the lower leaf surface and on their twigs at young stage. In contrast, 
Table 2 Composition (\%), water content (\%) and resulting nutrient inputs $(\mathrm{kg} / \mathrm{ha})$ of the fertilisers used

\begin{tabular}{llllll}
\hline Reference & Type & N & P & K & Water content \\
\hline C & 17-17-17 & 17 & 17 & 17 & 0 \\
& Organic fertiliser & 1.9 & 0.44 & 1.24 & 15 \\
& Total inputs (kg/ha) & 200 & 192 & 197 & \\
SNR & Staged nutrients release & 13 & 5.7 & 10.8 & 0 \\
& Total inputs (kg/ha) & 200 & 88 & 166 & \\
SS & Sewage sludge & 5.8 & 2.3 & 0.5 & 85.3 \\
& Total inputs (kg/ha) & 200 & 79 & 17 & \\
\hline
\end{tabular}

Grevillea exul ssp. rubiginosa possesses oblanceolate leaves and an ochre rubiginous tomentum on the lower leaf surface and on their twigs at young stage.

These species have been massively used for mine revegetation for more than 20 years: They are resistant to the dryness and can resist to low mineral supply. They are also recognised for their relatively rapid growth and they can provide large amount of non-dormant seeds that can germinate easily in several conditions (L'Huillier et al. 2010).

\section{Experimental design}

Collaboration with a major operator of nickel mining in New Caledonia (Société Le Nickel, SLN) allowed conducting experiments on two mine spoil piles at the Camp des Sapins mine, Thio, New Caledonia ( $21^{\circ} 45^{\prime} 55.30^{\prime \prime} \mathrm{S}, 166^{\circ} 10^{\prime} 35.07^{\prime \prime}$ E). The Camp des Sapins nickel mine is located on the main mountain chain that goes from the southeast to the northwest of Grande Terre, resulting in a 770-m elevation (see Fig. 2). Mean rainfall is $183 \mathrm{~mm}$ monthly but stronger precipitations may occur during the warm season from December to April with monthly rainfalls of up to $1000 \mathrm{~mm}$. The climate at the site is tropical with a mean annual temperature around $20^{\circ} \mathrm{C}$. Plantation was made in April 2012 before the dry season that occurs from September to November.

The aim of the experiment conducted was to assess the response of Geissois pruinosa and Grevillea exul after direct plantation on mine spoils (Topsoil-) or on mine spoils with addition of topsoil (Topsoil+). For each species, 1-year-old young plants produced from seeds in a tree nursery were obtained from 'Société Internationale de Réhabilitation et d'Aménagement de Sites' (SIRAS Pacifique). In the 'Topsoil+' treatment, addition of fresh, not compacted topsoil from the mine site was made on a $50-\mathrm{cm}$ layer upon ripped mine spoils. In each case, three fertilisers were also compared (Table 2). Fertilisers were added in holes along with a wet water-retaining additive before plantation. C and Staged Nutrient Release (SNR) are commercial fertilisers which mainly differ in their phosphorus content and the way they release nutrients. Sewage sludge (SS) is interesting as mines also proceed to on-site water treatment producing sludge that can be used in mine reclamation or restoration. The waterretaining additive used is a commercial sodium polyacrylate and the quantity added was equivalent to $5 \mathrm{~g}$ dry product per hole. After on-site plantation, each young plant was then covered with straw mulch as appears on Fig. 4. For each soil $\times$ fertiliser combination, four replicates were performed. A surface area of $2304 \mathrm{~m}^{2}$ was covered using 438 young plants of each species. For each replicate, 10 individuals were selected for experimental follow-up.

Table 3 presents the typical composition of the upper layer $(30 \mathrm{~cm})$ of the mine spoils and topsoil (ferritic ferralsol) at hand. Soil analyses were performed at Institut de Recherche pour le Développement (IRD, Noumea, New Caledonia) according to standard protocols (Pétard 1993). Mine spoils markedly differ from topsoil in terms of $\mathrm{pH}$, organic matter
Fig. 4 Views of Geissois pruinosa (left) and Grevillea exul (right) 20 months after plantation at the Camps des Sapins mine, Thio, New Caledonia
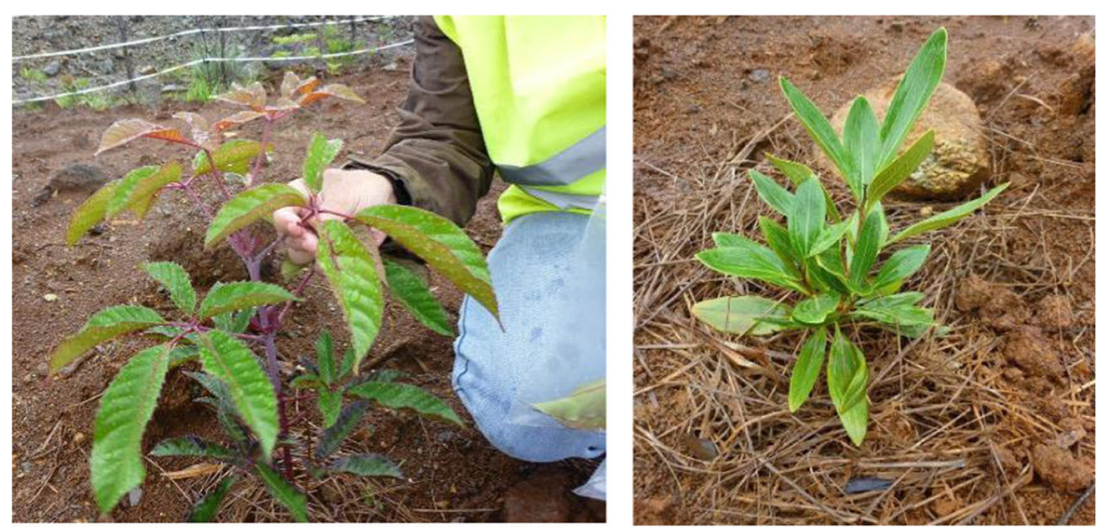
Table 3 Analyses of mine spoils and topsoil used (means and standard errors, $n=12$ for both substrates, asterisk indicates values that significantly differ with $P<0.01$ )

\begin{tabular}{|c|c|c|c|c|c|c|c|c|c|c|c|c|c|c|c|}
\hline & \multicolumn{2}{|l|}{$\mathrm{pH}$} & \multicolumn{2}{|c|}{$\mathrm{CN}(\%)$} & \multicolumn{2}{|c|}{$\mathrm{P}(\mathrm{mg} / \mathrm{kg})$} & \multicolumn{2}{|c|}{ DTPA (mg/kg) } & \multicolumn{2}{|c|}{ Total (mg/kg) } & \multicolumn{4}{|c|}{ Exchangeable cations (meq\%) } & \multirow{2}{*}{$\begin{array}{l}\text { CEC } \\
\text { meq\%* }\end{array}$} \\
\hline & $\mathrm{H}_{2} \mathrm{O}^{*}$ & $\mathrm{KCl}^{*}$ & $\mathrm{~N}^{*}$ & $\mathrm{C}^{*}$ & Tot & Av & $\mathrm{Mn}$ & $\mathrm{Ni}^{*}$ & $\mathrm{Mn} *$ & $\mathrm{Ni}$ & $\mathrm{Ca}^{*}$ & $\mathrm{Mg}^{*}$ & $\mathrm{Na}$ & $\mathrm{K}$ & \\
\hline \multirow[t]{2}{*}{ Topsoil } & 6.4 & 5.8 & 0.04 & 1.3 & 53 & 0.6 & 186 & 23 & 6150 & 8008 & 0.3 & 3.7 & 0.02 & 0.04 & 4.7 \\
\hline & 0.1 & 0.1 & 0.01 & 0.3 & 7 & 0.9 & 100 & 10 & 612 & 523 & 0.1 & 1.1 & 0.01 & 0.01 & 0.5 \\
\hline \multirow[t]{2}{*}{ Mine spoils } & 7.7 & 6.8 & 0.01 & 0.4 & 40 & 1.1 & 198 & 134 & 3645 & 9251 & 0.1 & 9.8 & 0.03 & 0.05 & 6.9 \\
\hline & 0.2 & 0.8 & 0.004 & 0.1 & 22 & 1.2 & 48 & 17 & 915 & 1935 & 0.04 & 2.3 & 0.02 & 0.05 & 0.9 \\
\hline
\end{tabular}

content and exchangeable cations. The usual excess $\mathrm{Mg}$ to $\mathrm{Ca}$ imbalance of ferritic ferralsols is more acute in mine spoils, but total and available phosphorus are similarly low. In terms of TE concentrations, total $\mathrm{Ni}$ and extractable $\mathrm{Mn}$ are similar for both soils, while total $\mathrm{Mn}$ is higher in topsoil and extractable Ni is significantly higher in mine spoils. From these data, challenging edaphic conditions appear for plant growth, and also interesting residual concentrations of $\mathrm{Ni}$ and $\mathrm{Mn}$ for phytoextraction.

\section{Sample and data analysis}

Simple parameters were retained for experimental follow-up: mortality, growth assessed by measuring plant heights and basal diameter, and measures of $\mathrm{Mn}$ or $\mathrm{Ni}$ concentrations in clean dry leaves. Statistical analysis of the results obtained was performed using XLSTAT.

Elemental concentrations in the plant material were performed as follows: Leaves were thoroughly cleansed (to prevent contamination from soil), air-dried $\left(48 \mathrm{~h}, 70{ }^{\circ} \mathrm{C}\right)$ and crushed. The resulting powder was digested in $65 \%$ nitric acid using a micro-wave closed vessel digestion system (Milestone Ethos Touch Micro-wave). The resulting solutions were filtered, diluted and analysed by inductively coupled plasma-mass spectrometry (ICP-MS). All reagents used for

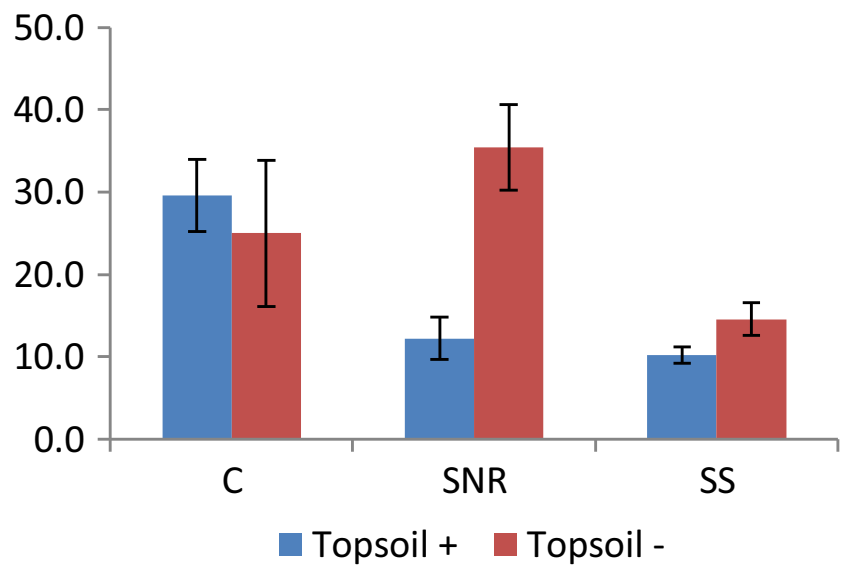

Fig. 5 Mortality (\% from initial population) for Geissois pruinosa $(C=$ control, $S N R=$ Stage Nutrient Release, $S S=$ sewage sludge) analyses were of high purity grades: Commercial $\mathrm{HNO}_{3}, \mathrm{HCl}$ and $\mathrm{H}_{2} \mathrm{O}_{2}$ were obtained from Sigma-Aldrich TraceSELECT ${ }^{\circledR}$ range. All solutions were prepared using double-deionised water (Milli-Q, Millipore, $18.2 \mathrm{M} \Omega \mathrm{cm}$ at $21{ }^{\circ} \mathrm{C}$ ). For each digestion procedure, blank and standard digestions were carried out the same way and analysed for controls. ICP-MS analyses were performed with a Thermo scientific X Series II ICP-MS (Plateforme AETE, HydroSciences/OSU OREME, Montpellier, France) using In and $\mathrm{Bi}$ as internal standards.

\section{Results and discussion}

Response of Geissois pruinosa

\section{Mortality}

Previous experiments using Geissois pruinosa in plantations on disused quarries showed high mortality during the first year but good development of the individuals that survived (Jaffré et al. 1993). Long-term survival of Geissois pruinosa can be

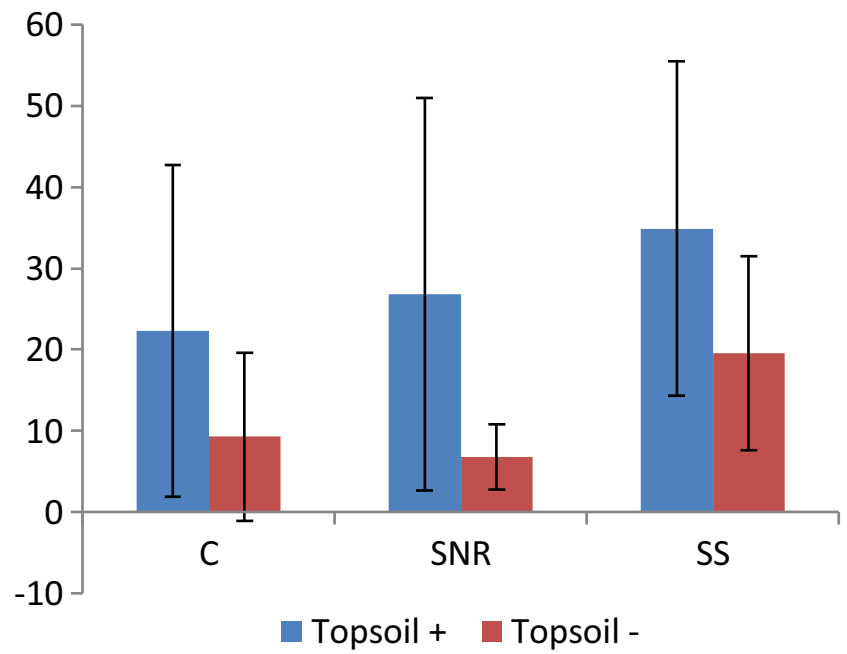

Fig. 6 Height increase from initial state (cm) for Geissois pruinosa $(C=$ control, $S N R=$ Stage Nutrient Release, $S S=$ sewage sludge) 
Fig. $7 \mathrm{Ni}$ concentrations $(\mathrm{mg} / \mathrm{kg})$ in the dry leaves of Geissois pruinosa $(C=$ control, $S N R=$ Stage Nutrient Release, $S S=$ sewage sludge, $Y L=$ young leaves, $O L=$ old leaves, $L=$ litter)
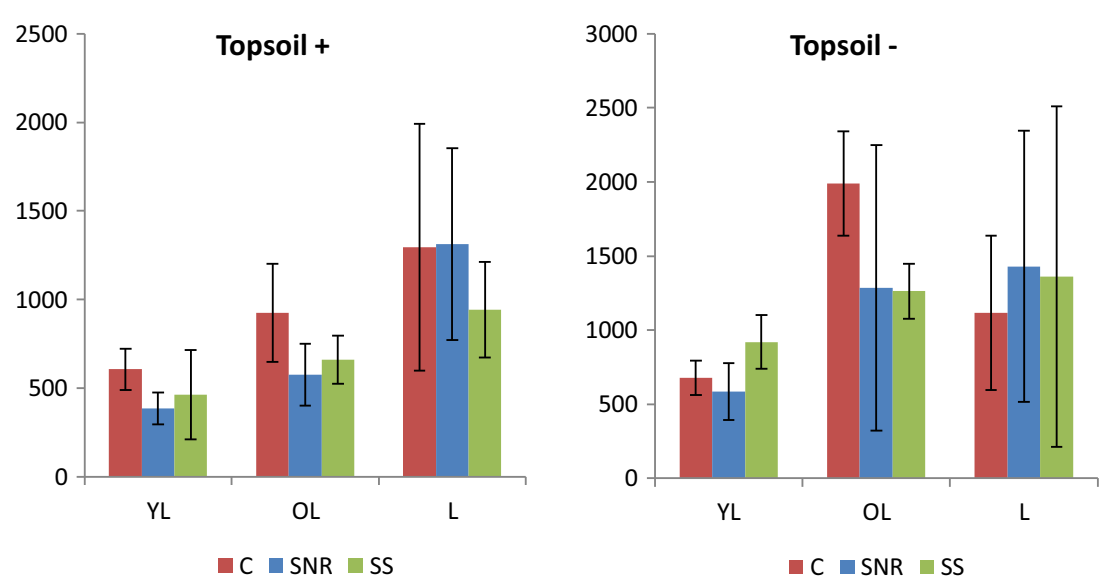

questioned as observations of early experiments after 20 years showed that the species disappeared. The main reasons for that appear to be the intensity of the dry season, low depth of soil on disused quarries, and coarse soil structure close to the parent bedrock. However, the quality of young plants used has improved since 1993, plus the use of fertilisers, efficient water-retaining additives and topsoil should provide significant improvements. Other experiments at the Mont-Dore showed good development of Geissois pruinosa after more than 15 years.

In our case, mortality after 20 months was $17 \%$ with topsoil addition against $25 \%$ with direct plantation on mine spoils (Fig. 5). However, it was not possible to find statistically significant relationships between mortality and the experimental parameters. As regards to temporal trends, mortality is still increasing but at a slower pace: $+0.8 \%$ monthly compared to an initial $+1.7 \%$. Mortality increases are similar on both soils, and for the three fertilisers used.

\section{Growth}

In the case of Geissois pruinosa, whether growth is assessed by using plant heights or their basal diameter does not result in different observations. In spite of high variability, ordered logistic regression showed soil type and treatments to significantly improve plant growth (Fig. 6). The best results are thus obtained using sewage sludge on topsoil. Although species on ultramafic soils are known to grow slowly (Enright et al. 2014), the response observed for Geissois pruinosa in these conditions is very encouraging. Further experiments should be conducted to find non-destructive biomass measurement methods, as growth is only a poor proxy for biomass.

\section{Ni accumulation}

A significant effect of leaf age on Ni concentrations was reported for the first time studying Psychotria gabriellae (ex. Psychotria douarrei) in its natural environment in New
Caledonia (Boyd et al. 1999). Further studies of leaf age effect in Ni hyperaccumulation showed similar response for two other species from New Caledonia: Homalium kanaliense and Geissois pruinosa (Boyd and Jaffré 2009). For this reason, we decided to sample young leaves (YL), old leaves (OL) and when possible dead leaf litters (L). Ordered logistic regression showed leaves $\mathrm{Ni}$ to be significantly influenced by soil type $\left(p<10^{-4}\right)$ and leaf age $\left(p<10^{-4}\right)$ but not by the type of fertiliser used (Fig. 7). Non-destructive biomass assessments are currently underway and should allow the selection of the fertiliser resulting in the highest biomass.

As expected from soil analyses (Table 3), direct plantation on mine spoils with higher available Ni (DTPA) resulted in higher concentrations in the plant leaves: Average OL concentration (regardless of the fertiliser used) is 1513( \pm 648$)$ $\mathrm{mg} \mathrm{kg}-1$ compared to $720( \pm 242) \mathrm{mg} \mathrm{kg}^{-1}$ with addition of topsoil. As regards to leaf age, on both soils, OL showed $\mathrm{Ni}$ concentrations that are two times those in YL. Ni concentrations observed in these experiments may seem low compared to the average composition of wild Geissois pruinosa: However, such measures probably targeted mature individuals without precise assessment of their ages. The case of dead

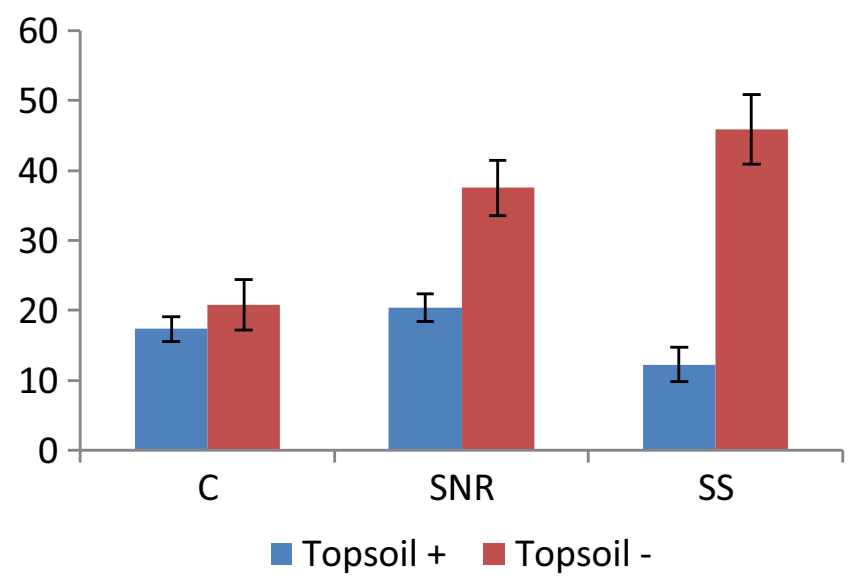

Fig. 8 Mortality (\% from initial population) for Grevillea exul $(C=$ control, $S N R=$ Stage Nutrient Release, $S S=$ sewage sludge) 


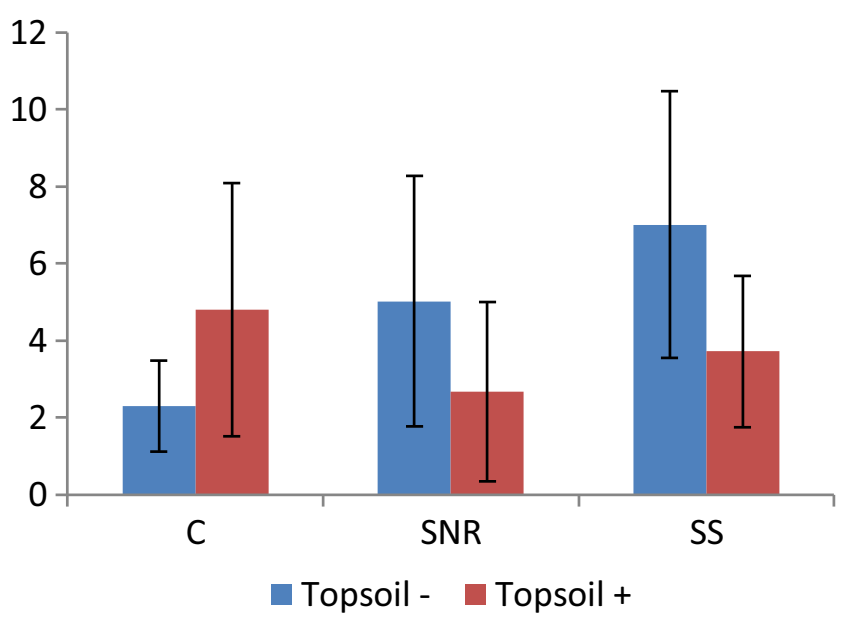

Fig. 9 Basal diameter increases from initial state $(\mathrm{mm})$ for Grevillea exul $(C=$ control, $S N R=$ Stage Nutrient Release, $S S=$ sewage sludge $)$

leaves that could be collected is more difficult: They show $\mathrm{Ni}$ concentrations comparable or higher than those in OL but could not be cleaned properly, as monitored from increased $\mathrm{Fe}$ or $\mathrm{Cr}$ concentrations. Soil contaminations result in higher standard deviations, and possibly overestimated Ni concentrations. Collection of clean dead leaves would be of interest to assess their potential applicability for the production of ecocatalysts. Decreasing N, P and K concentrations as these nutrients are recycled from senescent leaves may also result in increased Ni concentrations in dead leaves. Use of sole dead leaves would allow exploitation of the biomass for ecocatalysis, without stressing plants during leaves collection.

\section{Response of Grevillea exul}

\section{Mortality}

Previous experiments showed Grevillea exul to be one the most suitable plants for mine revegetation in New Caledonia (Jaffré et al. 1993). In this case, mortality is $17 \%$ with addition of topsoil against $35 \%$ with direct plantation on mine spoils, a difference that is statistically significant $\left(p<5 \cdot 10^{-2}\right)$. Fertilising treatments, however, have no significant effects on mortality (Fig. 8). As observed for Geissois pruinosa, mortality occurs at a slower rate: From $+1.9 \%$ monthly at the initial stage, it dropped to $+0.8 \%$ after 20 months. Longterm survival of Grevillea exul after plantation on mines appears to be quite successful: 15 - to 20-year-old individuals from previous experiments could be observed at Camp des Sapins (Jaffré et al. 1993).

\section{Growth}

Response of Grevillea exul is more surprising and is best assessed using stem diameter, which results in significant observations (Fig. 9). The effect of soil type is not significant and may change depending on the fertiliser used: $\mathrm{C}$ is the only fertiliser with which growth is improved on topsoil. SNR and SS result in better growth without topsoil. Phosphorus is known as a potentially toxic element to Proteaceae (Lamont 2003) and could be explaining such a response of Grevillea exul. Fertiliser used appears as a significant factor, and best results are obtained with SS, the treatment with lowest $\mathrm{P}$ inputs.

\section{Mn accumulation}

Recent reports of leaf age effects in Mn accumulation by Chengiopanax sciadophylloides, an Araliaceae from Japan (Mizuno et al. 2008), and observations on $\mathrm{Ni}$ hyperaccumulators from New Caledonia appeared as strong incentives to investigate leaf age effects in $\mathrm{Mn}$ accumulation by New Caledonian species. Influence of leaf age was also observed in Mn accumulator Grevillea gillivrayi from New Caledonia, yet without statistical significance. Thus, collection of Grevillea exul leaves was also performed separating YL, OL, and L. In this case, logistic regression proved leaf age $\left(p<10^{-4}\right)$, soil type $\left(p<10^{-4}\right)$ and fertilisers $(p<0.05)$ to significantly influence Mn concentration (Fig. 10). The highest Mn concentration at an average of $2000 \mathrm{mg} \mathrm{kg}^{-1}$ is thus found in old Grevillea exul leaves, with addition of topsoil, using sewage sludge as a fertiliser. Future evolution of this concentration will be of interest as average $\mathrm{Mn}$ concentrations in Grevillea exul do not exceed a mean $2833 \mathrm{mg} \mathrm{kg}^{-1}$.
Fig. 10 Mn concentrations (mg/ $\mathrm{kg}$ ) in the dry leaves of Grevillea exul $(C=$ control, $S N R=$ Stage Nutrient Release, $S S=$ sewage sludge, $Y L=$ young leaves, $O L=$ old leaves, $L=$ litter)
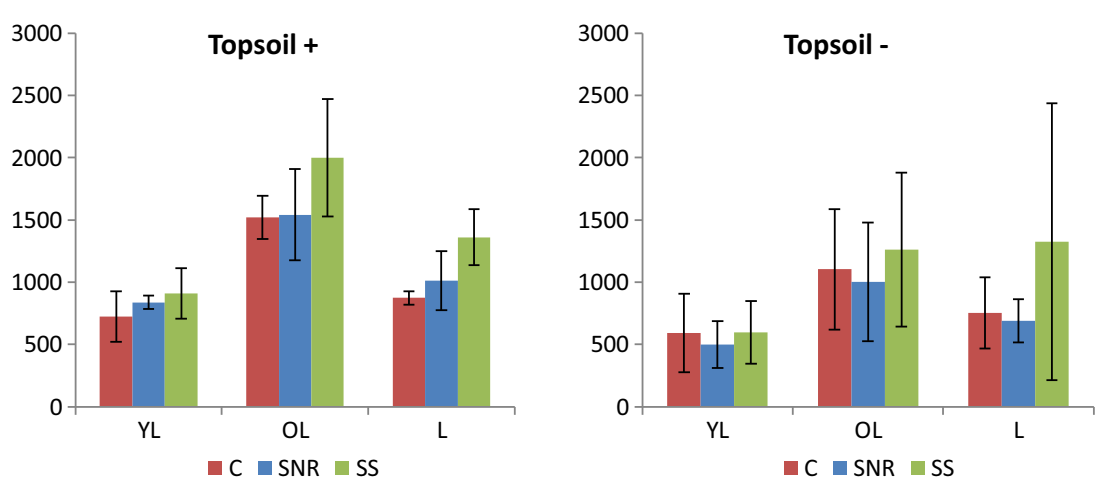
As regards to available $\mathrm{Mn}$, both soils are comparable while mine spoils show higher total $\mathrm{Mn}$ : This observation confirms that soil-plant relationships are not sufficient to fully account for TE hyperaccumulation. The case of $\mathrm{Mn}$ hyperaccumulator Denhamia fournieri (ex. Maytenus fournieri) from New Caledonia was recently discussed: Significant relationships between soil total $\mathrm{Mn}$ concentrations and those in leaves were found by Jaffré (1977) but not confirmed by later studies (Fernando et al. 2008). As regards to leaf age, OL concentrations are two times those in YL.

\section{Conclusion}

The experiments presented here are the first aiming to perform phytoextraction using tropical $\mathrm{Ni}$ or $\mathrm{Mn}$ hyperaccumulators endemic to New Caledonia. They are motivated by the development of ecocatalysis, a new approach to the exploitation of TE-rich biomass, which currently appears as the sole relevant outlet for the valuation of such biomass. More than substitutes for metals, ecocatalysts are new products that allow innovative approaches to green chemistry. Twenty months after starting our experiments on the possibility to produce Ni- or Mn-rich biomasss from Geissois pruinosa or Grevillea exul, the following conclusions may be drawn:

1. New techniques for the plantation of such species, using fertilisers as well as water-retaining compounds, can improve plant response in terms of mortality.

2. Plant growth was expected to be low but nonetheless allows expecting to obtain shrubs or small trees within reasonable time frames, e.g. 5 years. A precise nondestructive assessment of the biomass produced would nonetheless be required for a precise determination of potential phytoextraction yields.

3. Ni or Mn concentrations in young plants are lower than those usually measured in natural conditions for both species. Yet our observations show interesting soil and leaf age effects. Leaf age appears of major interest as it shows that using the oldest leaves or even dead leaves could be a relevant phytomining approach.

Perspectives to improve phytoextraction and make the approach more relevant in terms of its ecological objectives also appear: Cyperaceae, and other additional soil-improving species, could be used. They may provide an efficient way to control soil erosion and water flows on degraded land, as well as improve soil and ecological succession. Generating alternative incomes through the exploitation of metal-rich biomass used in ecocatalysis could not only cover the cost of the operation but also generate alternative economic activities for New Caledonia that needs to think beyond nickel.

Acknowledgments Financial support from the 'Agence Nationale pour la Recherche' (ANR 11ECOT01101), Société Le Nickel (SLN), and Ecole Polytechnique, Paris Tech (PhD studentship) is also gratefully acknowledged.

\section{References}

Baker A, Brooks R, Reeves R (1988) Growing for gold... and copper... and zinc. New Sci 116:44-48

Bani A, Echevarria G, Sulçe S, Morel JL (2013) Improving the agronomy of Alyssum murale for extensive phytomining: a five-year field study. Int J Phytoremed

Barbaroux R, Plasari E, Mercier G, Simonnot MO, Morel JL, Blais JF (2012) A new process for nickel ammonium disulfate production from ash of the hyperaccumulating plant Alyssum murale. Sci Total Environ 423:111-119. doi:10.1016/j.scitotenv.2012.01.063

Boyd RS, Jaffré T (2009) Elemental concentrations of eleven new caledonian plant species from serpentine soils: elemental correlations and leaf-age effects. Northeast Nat 16:93-110. doi:10.1656/045. 016.0508

Boyd RS, Jaffre T, Odom JW (1999) Variation in nickel content in the nickel-hyperaccumulating shrub Psychotria douarrei (Rubiaceae) from New Caledonia. Biotropica 31:403-410. doi:10.1111/j.17447429.1999.tb00382.x

Bradshaw AD Restoration after mining for metals - an ecological view. In: Jaffré T, Reeves RD, Becquer T, editors. Ecologie des milieux sur roches ultramafiques et sur sols métallifères., Nouméa, 1997. Documents scientifiques et techniques. ORSTOM, p 285-288

Brooks RR, Trow JM, Veillon JM, Jaffré T (1981) Studies on manganeseaccumulating alyxia species from new caledonia. Taxon 30:420 423. doi: $10.2307 / 1220141$

Brooks RR, Chambers MF, Nicks LJ, Robinson BH (1998) Phytomining. Trends Plant Sci 3:359-362. doi:10.1016/s1360-1385(98)01283-7

Callahan DL, Roessner U, Dumontet V, De Livera AM, Doronila A, Baker AJM, Kolev SD (2012) Elemental and metabolite profiling of nickel hyperaccumulators from New Caledonia. Phytochemistry 81: 80-89. doi:10.1016/j.phytochem.2012.06.010

Chaney RL, Malik M, Li YM, Brown SL, Brewer EP, Angle JS, Baker AJM (1997) Phytoremediation of soil metals. Curr Opin Biotechnol 8 doi:10.1016/s0958-1669(97)80004-3

Chaney R et al (2000) Improving metal hyperaccumulator wild plants to develop commercial phytoextraction systems: approaches and progress. In: Terry N, Banuelos G (eds) Phytoremediation of Contaminated Soil and Water. CRC Press, Boca Raton FL.

Chaney RL, Angle JS, Broadhurst CL, Peters CA, Tappero RV, Sparks DL (2007) Improved understanding of hyperaccumulation yields commercial phytoextraction and phytomining technologies. J Environ Qual 36:1429-1443. doi: $10.2134 /$ jeq 2006.0514

Cherrier JF (1990) Reconstitution of vegetative cover in mine areas in new caledonia. Bois ForetsTrop 5-23

Conesa HM, Schulin R (2010) The Cartagena - La Union mining district (SE spain): a review of environmental problems and emerging phytoremediation solutions after fifteen years research. J Environ Monit 12:1225-1233. doi:10.1039/c000346h

Conesa HM, Evangelou MWH, Robinson BH, Schulin R (2012) A critical view of current state of phytotechnologies to remediate soils: still a promising tool?. Sci World J 10 doi:10.1100/2012/173829 
Cunningham SD, Berti WR (1993) Remediation of contaminated soils with green plants - an overview. In Vitro Cell Dev Biol Plant 29P: 207-212

Dodson JR, Hunt AJ, Parker HL, Yang Y, Clark JH (2012) Elemental sustainability: towards the total recovery of scarce metals. Chem Eng Process 51:69-78. doi:10.1016/j.cep.2011.09.008

Enright NJ, Miller BP, Perry GLW, Goldblum D, Jaffré T (2014) Stresstolerator leaf traits determine population dynamics in the endangered New Caledonian conifer Araucaria muelleri. Aust Ecol 39: 60-71. doi:10.1111/aec. 12045

Ernst WHO (2000) Evolution of metal hyperaccumulation and phytoremediation hype. New Phytol 146:357-358. doi:10.1046/j. 1469-8137.2000.00669.x

Ernst WHO (2005) Phytoextraction of mine wastes - options and impossibilities. Chem Erde Geochem 65:29-42. doi:10.1016/j.chemer. 2005.06.001

Escande V, Olszewski TK, Grison C (2013) Preparation of ecological catalysts derived from $\mathrm{Zn}$ hyperaccumulating plants and their catalytic activity in Diels-Alder reaction. Comptes Rendus Chimie

Escande V et al (2014a) Ecological catalysis and phytoextraction: symbiosis for future. Appl Catalysis B-Environ 146:279-288. doi:10. 1016/j.apcatb.2013.04.011

Escande V, Tomasz O, Eddy P, Grison C (2014b) Biosourced polymetallic catalysts: an efficient means to synthesize underexploited platform molecules from carbohydrates. Chem Sus Chem: in press, doi: $10.1002 /$ cssc. 201400078

Faucon MP, Shutcha MN, Meerts P (2007) Revisiting copper and cobalt concentrations in supposed hyperaccumulators from SC Africa: influence of washing and metal concentrations in soil. Plant Soil 301:29-36. doi:10.1007/s11104-007-9405-3

Fernando DR, Woodrow IE, Jaffré T, Dumontet V, Marshall AT, Baker AJM (2008) Foliar manganese accumulation by Maytenus founieri (Celastraceae) in its native New Caledonian habitats: populational variation and localization by X-ray microanalysis. New Phytol 177: 178-185. doi:10.1111/j.1469-8137.2007.02253.x

Fogliani B, Hopkins HCF, Bouraima-Madjebi S, Medevielle V (2009) Morphological development of Geissois pruinosa (Cunoniaceae) from seed to adult, and the expression of plesiomorphic characters in seedlings. Flora 204:7-16. doi:10.1016/j.flora.2007.11.009

Grison C, Escande V (2013) Use of certain manganese-accumulating plants for carrying out organic chemistry reactions. WO2014016509-A1,

Grison C, Escande V (2013) Use of certain metal-accumulating plants for implementing organic chemistry reactions. WO 2013150197 A1.

Grison C, Escarre J (2011) Use of calcined plant/its part having accumulated at least one metal having zinc, nickel or copper to prepare composition having a metal catalyst for allowing the implementation of organic synthesis reactions e.g. halogenation of alcohols. WO2011064487-A1

Grison C, Escarre J (2011) Use of plant/its part having accumulated at least one metal having zinc, nickel or copper to prepare composition having a metal catalyst for allowing the implementation of organic synthesis reactions e.g. halogenation of alcohols. WO2011064462-A1

Grison C, Escande V, Petit E, Garoux L, Boulanger C, Grison C (2013) Psychotria douarrei and Geissois pruinosa, novel resources for the plant-based catalytic chemistry. RSC Advances 3:22340-22345. doi:10.1039/c3ra43995j

Hopkins H, Pillon Y (2011) Further new endemic taxa of Cunoniaceae from New Caledonia. Kew Bull 66:405-423

Hubbert MK (1956) Nuclear energy and the fossil fuels, vol 95. Shell Development Company, Exploration and Production Research Division Houston, TX

Hunt AJ et al (2014) Phytoextraction as a tool for green chemistry. Green Process Synth 3:3-22

Jaffré T (1977) Accumulation du manganèse par des espèces associées aux terrains ultrabasiques Comptes Rendus de l'Académie des sciences. Paris 284:1573-1575
Jaffré T (1979) Accumulation du manganèse par les proteacées de Nouvelle-Calédonie Comptes Rendus de l'Académie des sciences. Paris 285:425-428

Jaffré T, Schmid M (1974) Accumulation de nickel par une rubiacée de Nouvelle-Calédonie, Psychotria douarrei (G. Beauvisage) Däniker Compte Rendus de l'Académie des Sciences. Paris Sér D 278:17271730

Jaffré T, Brooks RR, Lee J, Reeves RD (1976) Sebertia acuminata: a hyperaccumulator of nickel from New Caledonia. Science 193:579580. doi:10.1126/science.193.4253.579

Jaffré T, Brooks RR, Trow JM (1979) Hyper-accumulation of nickel by geissois species. Plant Soil 51:157-162. doi:10.1007/bf02205937

Jaffré T, Rigault F, Sarrailh J-M (1993) Essais de revégétalisation par des espèces locales d'anciens sites miniers de la région de Thio. Nouméa

Jaffré T, Munzinger J, Lowry PP II (2010) Threats to the conifer species found on New Caledonia's ultramafic massifs and proposals for urgently needed measures to improve their protection. Biodivers Conserv 19:1485-1502. doi:10.1007/s10531-010-9780-6

Jaffré T, Pillon Y, Thomine S, Merlot S (2013) The metal hyperaccumulators from New Caledonia can broaden our understanding of nickel accumulation in plants. Front Plant Sci 4:279. doi: 10.3389/fpls.2013.00279

Kumar PBAN, Dushenkov V, Motto H, Raskin I (1995) Phytoextraction: the use of plants to remove heavy metals from soils. Environ Sci Technol 29:1232-1238

Lamont BB (2003) Structure, ecology and physiology of root clusters - a review. Plant Soil 248:1-19. doi:10.1023/a:1022314613217

Leon V et al (2005) Effects of three nickel salts on germinating seeds of Grevillea exul var. rubiginosa, an endemic serpentine proteaceae. Ann Bot 95:609-618. doi:10.1093/aob/mci066

L'Huillier L et al (2010) Mines et environnement en Nouvelle-Calédonie: les milieux sur substrats ultramafiques et leur restauration

Li YM et al (2003) Development of a technology for commercial phytoextraction of nickel: economic and technical considerations. Plant Soil 249:107-115. doi:10.1023/a:1022527330401

Losfeld G, de la Blache PV, Escande V, Grison C (2012) Zinc hyperaccumulating plants as renewable resources for the chlorination process of alcohols. Green Chem Lett Rev 5 doi:10.1080/ 17518253.2012.667157

Losfeld G, Escande V, de La Blache PV, L'Huillier L, Grison C (2012) Design and performance of supported Lewis acid catalysts derived from metal contaminated biomass for Friedel-Crafts alkylation and acylation. Catal Today 189 doi:10.1016/j.cattod.2012.02.044

Losfeld G, Escande V, Jaffré T, L'Huillier L, Grison C (2012c) The chemical exploitation of nickel phytoextraction: an environmental, ecologic and economic opportunity for New Caledonia. Chemosphere 89:907-910. doi:10.1016/j.chemosphere.2012.05. 004

Losfeld G, L'Huillier L, Fogliani B, Jaffré T, Grison C (2014) Mining in New Caledonia: environmental stakes and restoration opportunities. Environ Sci Pollut Res doi:10.1007/s11356-014-3358-x

Losfeld G, L'Huillier L, Fogliani B, Mc Coy S, Grison C, Jaffré T (2014) Leaf-age and soil-plant relationships: key factors for reporting traceelements hyperaccumulation by plants and design applications. Environ Sci Pollut Res doi:10.1007/s11356-014-3445-Z

Merlot S, Hannibal L, Martins S, Martinelli L, Amir H, Lebrun M, Thomine S (2014) The metal transporter PgIREG1 from the hyperaccumulator Psychotria gabriellae is a candidate gene for nickel tolerance and accumulation. J Exp Bot eru025

Mizuno T, Asahina R, Hosono A, Tanaka A, Senoo K, Obata H (2008) Age-dependent manganese hyperaccumulation in Chengiopanax sciadophylloides (Araliaceae). J Plant Nutr 31:1811-1819. doi:10. 1080/01904160802325396

Morat $\mathrm{P}$ et al (2012) The taxonomic reference base Florical and characteristics of the native vascular flora of New Caledonia. Adansonia 34:179-221 
Mudd G, Ward J Will (2008) Sustainability constraints cause "peak minerals". In: 3rd International Conference on Sustainability Engineering and Science: Blueprints for Sustainable Infrastructure. Auckland

Oregon Department of Agriculture (2014) ODA Plant Programs, Noxious Weed Control yellow tuft (Alyssum murale, A. corsicum). http:// www.oregon.gov/ODA/PLANT/WEEDS/pages/weed_yellowtuft. aspx

Pelletier B (2006) Geology of the New Caledonia region and its implications for the study of the New Caledonian biodiversity Compendium of marine species from New Caledonia 17-30

Pétard J (1993) Les méthodes d'analyse: tome 1. Analyse de sols

Pillon Y, Hopkins HCF, Rigault F, Jaffré T, Stacy EA (2014) Cryptic adaptive radiation in tropical forest trees in New Caledonia. New Phytol 202:521-530. doi:10.1111/nph.12677

Rabier J et al (2007) Characterization of metal tolerance and accumulation in Grevillea exul var exul. Int J Phytoremed 9:419-435. doi:10. 1080/15226510701606315

Rabier J, Laffont-Schwob I, Notonier R, Fogliani B, Bouraima-Madjebi S (2008) Anatomical element localization by EDXS in Grevillea exul var. exul under nickel stress. Environ Pollut 156:1156-1163. doi:10. 1016/j.envpol.2008.04.001

Raskin I, Ensley BD (2000) Phytoremediation of toxic metals: using plants to clean up the environment. Wiley, New York

Reeves RD (1992) The hyperaccumulation of nickel by serpentine plants. Veg Ultramafic (Serpentine) Soils 253-277

Reeves RD (2003) Tropical hyperaccumulators of metals and their potential for phytoextraction. Plant Soil 249:57-65. doi:10.1023/ a: 1022572517197

Robinson BH (1997) The phytoextraction of heavy-metals from metalliferous soils. Massey University

Robinson B, Fernandez JE, Madejon P, Maranon T, Murillo JM, Green S, Clothier B (2003) Phytoextraction: an assessment of biogeochemical and economic viability. Plant Soil 249:117-125. doi:10.1023/ a: 1022586524971
Sas-Nowosielska A, Kucharski R, Malkowski E, Pogrzeba M, Kuperberg JM, Krynski K (2004) Phytoextraction crop disposal — an unsolved problem. Environ Pollut 128:373-379. doi:10.1016/j.envpol.2003. 09.012

Tang Y-T et al (2012) Designing cropping systems for metalcontaminated sites: a review. Pedosphere 22:470-488

Thillier Y, Losfeld G, Escande V, Dupouy C, Vasseur J-J, Debart F, Grison C (2013) Metallophyte wastes and polymetallic catalysis: a promising combination in green chemistry. The illustrative synthesis of 5 'capped RNA. RSC Advances 3:5204-5212. doi:10.1039/c3ra23115a

Tordoff GM, Baker AJM, Willis AJ (2000) Current approaches to the revegetation and reclamation of metalliferous mine wastes. Chemosphere 41:219-228. doi:10.1016/s0045-6535(99)00414-2

van der Ent A, Baker AJM, Reeves RD, Pollard AJ, Schat H (2013a) Hyperaccumulators of metal and metalloid trace elements: facts and fiction. Plant Soil 362:319-334. doi:10.1007/s11104-012-1287-3

van der Ent A, Baker AJM, van Balgooy MMJ, Tjoa A (2013b) Ultramafic nickel laterites in Indonesia (Sulawesi, Halmahera): mining, nickel hyperaccumulators and opportunities for phytomining. J Geochem Explor 128:72-79. doi:10.1016/j.gexplo.2013.01.009

Van Nevel L, Mertens J, Oorts K, Verheyen K (2007) Phytoextraction of metals from soils: how far from practice?. Environ Pollut 150 doi: 10.1016/j.envpol.2007.05.024

Verhoef EV, Dijkema GPJ, Reuter MA (2004) Process knowledge, system dynamics, and metal ecology. J Ind Ecol 8:23-43. doi:10.1162/ 1088198041269382

Wellmer F-W (2012) Sustainable development and mineral resources vol 15. BRGM

Whiting SN et al (2004) Research priorities for conservation of metallophyte biodiversity and their potential for restoration and site remediation. Restor Ecol 12:106-116. doi:10.1111/j.1061-2971. 2004.00367.x

Wolfe AK, Bjornstad DJ (2002) Why would anyone object? An exploration of social aspects of phytoremediation acceptability. Crit Rev Plant Sci 21:429-438. doi:10.1080/0735-260291044304 